\title{
Systemic Acquired Resistance of Soybean to Soybean Rust Induced by Shale Water
}

\author{
Yeshwant R. Mehta1 ${ }^{*}$, Mariana S. Marangoni1, Janaina N. Matos1, \\ José Marcos G. Mandarino², Rafael Galbieri ${ }^{3}$ \\ ${ }^{1}$ Instituto Agronômico do Paraná-IAPAR, Rodovia Celso Garcia Cid, Londrina, Brazil \\ ${ }^{2}$ Embrapa Soja, Londrina, Brazil \\ ${ }^{3}$ Instituto Mato-Grossense do Algodão (IMA), Primavera do Leste, Brazil \\ Email: *yeshwantrmehta@gmail.com
}

Received 22 July 2015; accepted 1 September 2015; published 4 September 2015

Copyright (C) 2015 by authors and Scientific Research Publishing Inc.

This work is licensed under the Creative Commons Attribution International License (CC BY).

http://creativecommons.org/licenses/by/4.0/

(c) (i) Open Access

\section{Abstract}

Shale water as a by-product obtained by Petrobras, Brazil, during the process of extraction of petroleum from fossil rock may act as an inducer of Systemic Acquired Resistance (SAR) to some plant pathogens. The objective of the present investigation was to verify the effect of seed treatment and foliar application with shale water in inducing SAR of soybean to soybean rust under greenhouse and field conditions. In greenhouse experiments, seed treatment alone with shale water significantly reduced the severity of soybean rust and the control efficiency after 11 and 14 days after inoculation was between $54.1 \%$ and $57.8 \%$. Whereas seed treatment and only one foliar application with shale water the control efficiency due to SAR 14 and 11 days after inoculation was between $\mathbf{9 9 . 7 \%}$ and $100 \%$, respectively. Such treatments gave similar results under field experiments where the control efficiency of soybean rust was between $79.0 \%$ and $99.35 \%$ in shale water treated plots as compared to the untreated plots, in 2015. Consequently, this resulted in yield increase between $\mathbf{1 4 . 8 \%}$ and $\mathbf{2 8 . 8 \%}$ depending upon the seed treatment and foliar applications with shale water alone or in mixture with a fungicide. Seed health testing revealed lower number of seeds infected with some pathogens in treatments where either shale water or fungicide was used. Seed treatment and one foliar application were sufficient to induce SAR against soybean rust. This is the first report to demonstrate SAR of soybean to soybean rust induced by shale water. Patent regarding this investigation is deposited with Petrobras, Brazil, under the number EVP 14/022.

\section{Keywords}

Glycine max, Phakospora pachyrhizi, Asian Soybean Rust

\footnotetext{
${ }^{*}$ Corresponding author.
}

How to cite this paper: Mehta, Y.R., Marangoni, M.S., Matos, J.N., Mandarino, J.M.G. and Galbieri, R. (2015) Systemic Acquired Resistance of Soybean to Soybean Rust Induced by Shale Water. American Journal of Plant Sciences, 6, 2249-2256. 


\section{Introduction}

Soybean rust caused by the fungus Phakospora pachyrhizi is the most important disease in Brazil, causing heavy yield losses. The disease is partially controlled by use of early maturing varieties and applications of 2 - 4 fungicides during the season depending when the disease first appears in the field. In the absence of management practices, the disease can cause yield losses of up to $90 \%$. Total grain losses due to the soybean rust in Brazil may be over US $\$ 220.50$ per ton [1]. Therefore the use of resistant varieties and crop rotation are recommended to manage the disease [1] [2]. Most of the soybean varieties available for cultivation are susceptible to soybean rust. Some resistant varieties have been identified however the majority are not yet recommended for commercial production. It is possible that the resistance of these varieties varies based on climatic conditions and the aggressiveness of the rust pathotypes. In Brazil, about $38 \%$ of the soybean seeds are pirated which limits the use of seeds of resistant varieties [3]. Other than the soybean rust downy mildew caused by Peronospora manshurica could also be economically important in some regions.

One alternative to control the soybean rust could be the induction of Systemic Acquired Resistance (SAR). SAR is associated with accumulation of pathogenesis-related genes ( $P R$ genes) in both local and systemic tissues. Durrant and Dong, 2004 [4] have given a comprehensive account of the molecular basis of SAR. They suggest that the SAR induced genes include effector genes that confer resistance as well as regulatory genes such as transcription factors that confer that resistance is long lasting in the plant. Benzothiadiazole as a novel class of inducers of SAR, has been developed commercially as a plant activator, inducing SAR in wheat and conferring systemic protection against powdery mildew [5] [6]. Vigo et al., 2012 [6] reported that chemicals like pyraclostrobin and acibenzolar-S-methyl sprayed on snap bean induced systemic resistance against common bacterial blight caused by Xanthomonas axonopodis pv. phaseoli. In most cases SAR is due to the presence of salicylic acid and is associated with the accumulation of pathogenesis-related proteins [4] [7] [8]. Shale water is obtained during the pyrolytic decomposition of organic material of fissile rock petroleum. There are several reports regarding the use of retorted shale but very few reports are available in the literature about the shale water [9]-[11]. Shale water contains several macro and micro elements including phosphorus and salicylic acid [12] [13]. One hypothesis is that due to the presence of such elements the shale water may act as inducer of SAR against soybean rust. Recently, SAR of cotton, soybean and common bean to Rhizoctonia solani and Sclerotium rolfsii induced by shale water seed treatment was demonstrated [14]. These authors presented strong evidence of SAR induced by shale water seed treatment. For this reason, the objective of this investigation was to verify the effect of seed treatment and foliar applications of shale water on soybean to induce SAR against soybean rust under greenhouse and field conditions.

\section{Materials and Methods}

\subsection{Shale Water}

Shale water was obtained from Petrobras (petrochemical extraction industry) located at Irati (São Mateus do Sul), PR, Brazil. Shale water is produced by retorting bitumen shale during the process of pyrolytic decomposition of organic material process known as PETROSIX. It was prepared as described earlier [14]. After distillation of the shale water for one and a half hour the volatile substance is fixed with $4 \%$ of Dodecil Sodium Sulfate (also commercially known as Lauryl in Brazil). Later, soybean oil (1\%) was added as a spreader and the finished product was stored at room temperature in the dark for further use. The final composition of shale water is also referred as EAX (Extrato Aquoso de Xisto) in Brazil.

\subsection{In Vitro Test}

The effect of shale water on the germination of uredinospores of soybean rust under laboratory conditions was studied. For this purpose a suspension of uredinospores of soybean rust was spread on Petri plates containing water agar with or without shale water (5\%). The plates were incubated at room temperature for $16 \mathrm{~h}$ and were examined under microscope to verify uredinospore germination.

\subsection{Greenhouse Experiments}

Two greenhouse experiments were performed to verify whether shale water induces SAR in a susceptible culti- 
var BRS 232 obtained from National Resource Center of Soybean, Embrapa. In both experiments 150 seeds (50 seeds in three replications) were treated with shale water $(0.5 \%)$ in a plastic bag for two minutes and were sown soon after the treatment in plastic trays $(30 \times 20 \times 12 \mathrm{~cm})$ containing a mixture of soil, sand and compost in equal proportions. The greenhouse temperature was maintained at about $22^{\circ} \mathrm{C}$.

In the first experiment the treatments were: $\mathrm{T} 1$-Check (without seed treatment and without foliar application of shale water); T2-Seeds treated with 5\% shale water but without foliar application of shale water; T3-Seeds treated with $5 \%$ shale water and with one foliar application of shale water (5\%) made $24 \mathrm{~h}$ before inoculation; T4-Seeds not treated but with one foliar application of shale water (5\%) made $24 \mathrm{~h}$ before inoculation. Plants were sprayed with equal amount of shale water per tray using a hand sprayer.

The second experiment was similar to the first experiment except that two additional treatments were added: T5-Seeds treated with $5 \%$ shale water and two foliar applications with shale water (5\%) and, T6-Seeds treated with $5 \%$ shale water and three foliar applications of shale water (5\%).

Plants of each tray were spray inoculated 25 days after sowing using a urediniospore suspension of $1 \times 10^{6}$ uredinospores per $\mathrm{ml}\left(50 \mathrm{ml}\right.$ per tray). The inoculated plants were incubated overnight in the dark at $22^{\circ} \mathrm{C}$ and almost at $100 \%$ humidity and later transferred to the greenhouse. The first foliar spray application of shale water was made $24 \mathrm{~h}$ before inoculation. Second and the third foliar sprays were made with an interval of 12 days.

Rust pustules were counted 11 to 41 days after inoculation on 10 highly infected trifoliate leaves per treatment. Total leaf area was estimated and the number of rust pustules per $\mathrm{cm}^{2}$ of the leaf area was determined. The leaf area was estimated using the portable area meter Li-COR, model LI-3000 (LAMDA Instruments Corp., Lincoln, $\mathrm{NE}$ ). Other parameters to estimate rust such as pustule size and pustule color were not used. Trifoliate leaves showing more than 300 pustules per $\mathrm{cm}^{2}$ were not considered for pustule counting.

\subsection{Statistical Analysis}

The experimental design of the greenhouse experiments was a randomized blocks with three replications. Data were compared by analysis of variance using Tukey $5 \%$.

Control efficiency of soybean rust was calculated by the following formula:

Control efficiency (\%)

$=\frac{\text { Number of rust pustules of the check plants }- \text { Number of rust pustules of the treated plants }}{} \times 100$. Number of pustules of the check plants

\subsection{Field Experiments}

Field experiments were conducted at IAPAR, Londrina, PR, Brazil, during 2013-2014 and 2014-2015, using a susceptible soybean cultivar BMX Força. Foliar sprays with shale water were made with a $\mathrm{CO}_{2}$ backpack sprayer calibrated to deliver $500 \mathrm{ml}$ per plot. The field plots were $10 \mathrm{~m}^{2}$ and consisted of four rows of $5.0 \mathrm{~m}$ long. Experimental design was randomized blocks with five replications.

The treatments were: $\mathrm{T} 1$ = Check-without seed treatment and without foliar application; $\mathrm{T} 2$ = Seeds treated with shale water (5\%) and three foliar applications of shale water (25\%); T3 = Seeds treated with shale water and three foliar applications with a mixture of shale water $(25 \%)+$ piraclostrobin $133 \mathrm{~g}^{-1}+$ epoxiconazol $50 \mathrm{~g} \mathrm{~g}^{-1}$; $\mathrm{T} 4=$ Seeds treated with $5 \%$ of shale water and three foliar applications of the piraclostrobin $133 \mathrm{~g}^{-1}+$ epoxiconazol $50 \mathrm{~g} \mathrm{~g}^{-1}$ fungicide alone. Seeds treatment was done with $5 \%$ of shale water using $5.0 \mathrm{ml}$ per $100 \mathrm{~kg}$ seeds, and were planted soon after the treatment. Piraclostrobin $133 \mathrm{~g}^{-1}+$ epoxiconazol $50 \mathrm{~g}^{-1}$ (commercially known as Opera in Brazil) is one of the officially recommended fungicides to control soybean diseases in Brazil, and was arbitrarily selected for field experiments. Foliar applications were made with an interval of 12 days starting at first appearance of the rust symptoms 75 days after sowing. In both field experiments no artificial inoculation was made. Disease severity was noted at growth stage R6 [15] by visual assessment of the percentage of the leaf area infected using 10 highly infected trifoliate leaves in a diagonal fashion per plot [16]. The percent increase in yield due to SAR activity in shale water treated plots was calculated using a similar statistical analysis as explained earlier for the greenhouse experiments including the formula for calculation of control efficiency.

\section{Results}

In the in vitro test germination of uredinospores was completely inhibited in water agar containing $5 \%$ shale 
water. There was no inhibition in the control plates (Figure 1). Only one concentration was used in this test since earlier in vitro studies indicated that for bacterial pathogens $4 \%$ shale water and for fungal pathogens $5 \%$ shale water completely inhibited the spore germination or growth of these pathogens (unpublished data).

In both greenhouse experiments, shale water seed treatment alone reduced the number of rust pustules that developed 11 and 14 days after inoculation by nearly $50 \%$. This represented control efficiency between $42.2 \%$ and 54.5\% (Table 1, Table 2). After 28 and 33 days after inoculation the number of rust pustules that developed

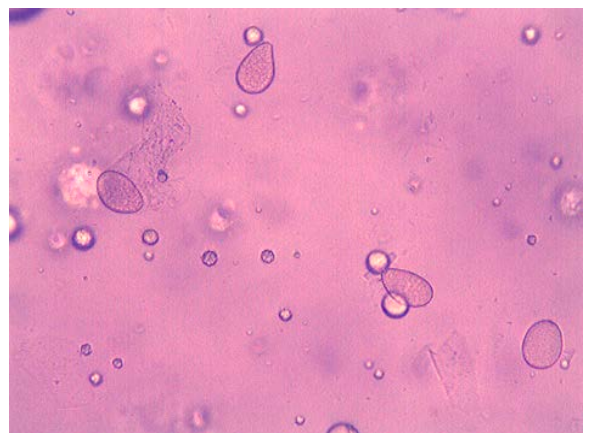

(a)

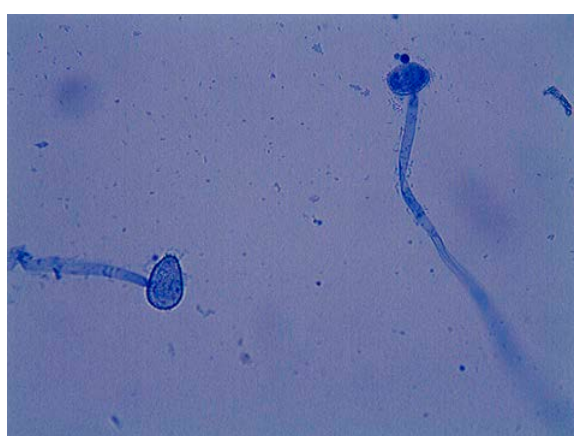

(b)

Figure 1. Inhibition of germination of soybean rust spores caused by shale water. (a) Uredinospore suspension in plates of water-agar containing $5 \%$ of shale water inhibiting uredinospore germination; (b) Uredinospore suspension in plates of water-agar with no shale water showing germination of uredinospores $48 \mathrm{~h}$ after incubation. The size of the uredinospore is $18-$ $45 \times 13-28 \mu$, depending upon the soybean culture.

Table 1. Effect of seed treatment and foliar applications of soybean seedlings with shale water on the severity of soybean rust under greenhouse conditions*.

\begin{tabular}{|c|c|c|c|}
\hline \multirow{2}{*}{ Treatment $^{* *}$} & \multicolumn{2}{|c|}{ Number of rust pustules per $\mathrm{cm}^{2^{* * *}}$} & \multirow{2}{*}{$\begin{array}{c}\text { Control efficiency (\%) } \\
14 \text { d after inoculation }\end{array}$} \\
\hline & $14 \mathrm{~d}$ after inoculation & $28 \mathrm{~d}$ after inoculation & \\
\hline $\mathrm{T} 1$ & $74.55 a$ & $* * * *$ & - \\
\hline $\mathrm{T} 2$ & $43.09 \mathrm{~b}$ & 73.81a & 42.2 \\
\hline Т3 & $0.24 \mathrm{c}$ & $4.36 \mathrm{a}$ & 99.7 \\
\hline $\mathrm{T} 4$ & $0.45 c$ & $2.26 \mathrm{a}$ & 99.4 \\
\hline
\end{tabular}

${ }^{*}$ Average of 20 replications. ${ }^{* *}$ T1 —Check (without seed treatment and without foliar application of shale water); T2—Seeds treated with $5 \%$ shale water but without foliar application of shale water; T3-Seeds treated with $5 \%$ shale water and with one foliar application of shale water (5\%) made 24 h before inoculation; T4-Seeds not treated but with one foliar application of shale water (5\%) made 24 h before inoculation; ${ }^{* * *}$ rust inoculation was done $24 \mathrm{~h}$ after shale water application; ${ }^{* * * *}$ Number of rust pustules $>300$ per $\mathrm{cm}^{2}$ was not counted. Treatments with similar letters do not differ (Tukey 5\%).

Table 2. Effect of seed treatment and foliar applications of soybean seedlings with shale water on the severity of soybean rust under greenhouse conditions.

\begin{tabular}{ccccc}
\hline Treatment $^{*}$ & \multicolumn{2}{c}{ Number of rust pustules per $\mathrm{cm}^{2}$ days after } & inoculation & Control efficiency (\%) days after inoculation \\
\cline { 2 - 4 } & 11 & 33 & 41 & 11 \\
\hline T1 & $72.34 \mathrm{a}$ & $* * *$ & & - \\
$\mathrm{T} 2$ & $39.10 \mathrm{~b}$ & $86.24 \mathrm{a}$ & $87.52 \mathrm{a}$ & 54.05 \\
$\mathrm{~T} 3$ & $0.00 \mathrm{c}$ & $3.57 \mathrm{~b}$ & $3.04 \mathrm{~b}$ & 100.0 \\
$\mathrm{~T} 4$ & $0.11 \mathrm{c}$ & $2.62 \mathrm{~b}$ & $2.33 \mathrm{~b}$ & 99.85 \\
$\mathrm{~T} 5$ & $0.00 \mathrm{c}$ & $1.57 \mathrm{~b}$ & $1.29 \mathrm{~b}$ & 100.0 \\
T6 & $0.00 \mathrm{c}$ & $2.28 \mathrm{~b}$ & $0.07 \mathrm{~b}$ & 100.0 \\
\hline
\end{tabular}

Figures are averages of 10 replications. ${ }^{*}$ T1 —Check (without seed treatment and without foliar application of shale water; T2 —Seeds treated with $5 \%$ shale water but without foliar application of shale water; T3-Seeds treated with 5\% shale water and with one foliar application of shale water (5\%) made $24 \mathrm{~h}$ before inoculation; T4—Seeds not treated but with one foliar application of shale water (5\%) made 24 h before inoculation; T5 — Seeds treated with 5\% shale water and two foliar applications with shale water (5\%); T6 - Seeds treated with 5\% shale water and three foliar applications of shale water (5\%). ${ }^{* *}$ Rust inoculation was done 24 days after sowing; ${ }^{* * *}$ The first application of shale water was done $24 \mathrm{~h}$ before inoculation, the second and the third applications were done 26 and 34 days after inoculation respectively. Number of rust pustules $>300$ per cm ${ }^{2}$ was not counted. Treatments with similar letters do not differ. (Tukey 5\%, MSD = 33.24). 
was much lower when compared to the check. Whereas seed treatment and only one foliar application with shale water the control efficiency of soybean rust was between $99.7 \%$ and $100 \%$, respectively (Table 1, Table 2).

No statistical difference was observed between one and three foliar applications with shale water (Table 2). Considering the two greenhouse experiments, after 28 - 33 days after inoculation the number of rust pustules per $\mathrm{cm}^{2}$ in the check plants were over 300. In the shale water seed treatment alone the significant reduction in the number of rust pustules could be observed until 41 days after inoculation indicating that the SAR activity was long lasting (Table 1, Table 2). Treatments with one or three foliar applications showed few rust pustules compared to the check. There was no indication of any toxic effect of the seedlings by shale water treatment.

Seed treatment and foliar applications gave similar results in field experiments where the control efficiency of soybean rust was between $89.7 \%$ and $99.35 \%$ in 2014 and between $79.0 \%$ and $96.9 \%$ in 2015 , as compared to the untreated plots. Consequently this resulted in yield increase between $14.8 \%$ and $28.8 \%$ in 2015 .The control efficiency of soybean rust in treated plots was between $48.7 \%$ and $90.0 \%$ compared to untreated check. In field experiment conducted during 2013-2014, the severity of soybean rust in check plots was $54.18 \%$ whereas in plots with seed treatment and three foliar applications it was only $5.54 \%$, representing control efficiency of 89.7\%. Similarly, in the field experiment conducted in 2014-2015, the rust severity in check plots was $63.51 \%$ as compared to $14.32 \%$ in plots with seed treatment and foliar applications with shale water representing control efficiency of $77.45 \%$. This resulted in yield increase of $14.8 \%-28.8 \%$ as compared with the check plots (Table 3, Table 4 and Figure 2). The yield data of 2013-2014 field experiment was lost due to poor environmental conditions during harvest since the plots were destroyed and were not harvested.

It is interesting to note that the use of shale water did not affect protein and oil content of harvested grains according to the grain analysis based on FT-NIR Spectroscopy as suggested by Heil, 2010 [17] (Table 4). Seed health testing revealed lower number of seeds infected by some pathogens in treatments where either shale water or fungicide was sprayed as compared to the check plots. None of the treatments showed reduction in the number of seeds infected by Cercospora kikuchi (Table 5).

These results demonstrate that seed treatment and a single foliar application with shale water would be sufficient to induce SAR against soybean rust (Table 1, Table 2). Other than the SAR activity shale water offers an additional advantage of inhibiting uredinospores germination of soybean rust (Figure 1).

Table 3. Effect of seed treatment and foliar application with shale water alone or in combination with fungicide on the percentage of leaf area infected with soybean rust under field experiment conducted during 2013-2014.

\begin{tabular}{ccc}
\hline Treatment $^{*}$ & \% Leaf area infected by soybean rust $^{* *}$ & Control efficiency $(\%)^{* *}$ \\
\hline T1 & $54.18 \mathrm{a}$ & - \\
T2 & $5.54 \mathrm{~b}$ & 89.77 \\
T3 & $0.52 \mathrm{cb}$ & 99.00 \\
T4 & $0.35 \mathrm{c}$ & 99.35 \\
\hline
\end{tabular}

${ }^{*} \mathrm{~T} 1$ = Check-without seed treatment and foliar application; T2 = Seeds treated with shale water (5\%) and three foliar applications of shale water $(25 \%)$; T3 = Seeds treated with shale water and three foliar applications with a mixture of shale water $(25 \%)+$ piraclostrobin $133 \mathrm{~g}^{-1}+$ epoxiconazol $^{2}$

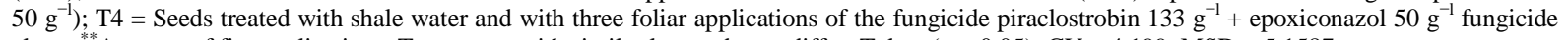
alone. ${ }^{* *}$ Average of five replications. Treatments with similar letters do not differ. Tukey $(\mathrm{p}=0.05)$; CV $=4.199, \mathrm{MSD}=5.1587$.

Table 4. Effect of seed treatment and foliar application with shale water alone or in combination with fungicide on the percentage of leaf area infected with soybean rust, yield, and seed quality, under field experiment conducted during 2014-2015*.

\begin{tabular}{|c|c|c|c|c|c|c|}
\hline Treatment $^{* *}$ & $\begin{array}{l}\text { \% leaf area infected } \\
\text { with soybean rust }\end{array}$ & $\begin{array}{c}\text { Control efficiency } \\
\text { (\%) }\end{array}$ & $\begin{array}{l}\text { Yield }^{* * *} \\
\left(\mathrm{Kg}^{*} \mathrm{ha}^{-1}\right)\end{array}$ & $\begin{array}{l}\text { \% increase in } \\
\text { relation to check }\end{array}$ & Protein content $^{* * * *}$ & Oil content ${ }^{* * * *}$ \\
\hline $\mathrm{T} 1$ & $63.51 \mathrm{a}$ & - & $4.200 \mathrm{c}$ & - & 37.5 & 21.3 \\
\hline $\mathrm{T} 2$ & $14.32 \mathrm{~b}$ & 77.45 & $4.823 \mathrm{~b}$ & 14.8 & 37.6 & 21.6 \\
\hline Т3 & 20.62 bc & 67.53 & $5.409 \mathrm{a}$ & 28.8 & 37.1 & 21.8 \\
\hline $\mathrm{T} 4$ & $8.32 \mathrm{c}$ & 86.9 & 5.329 a & 26.9 & 37.4 & 21.7 \\
\hline
\end{tabular}

${ }^{*}$ Figures are averages of five replications. ${ }^{* *} \mathrm{~T} 1=$ Check-without seed treatment and foliar application; T2 = Seeds treated with shale water (5\%) and three foliar applications of shale water (25\%); T3 = Seeds treated with shale water and three foliar applications with a mixture of shale water (25\%) + piraclostrobin $133 \mathrm{~g}^{-1}+$ epoxiconazol $50 \mathrm{~g}^{-1}$ ); $\mathrm{T} 4$ = Seeds treated with shale water and with three foliar applications of the fungicide piraclostrobin $133 \mathrm{~g}^{-1}+$ epoxiconazol $50 \mathrm{~g}^{-1}$ alone. ${ }^{* * * *}$ Treatments with similar letters do not differ. Tukey $(\mathrm{p}=0.05) ; \mathrm{CV}=4.415, \mathrm{MSD}=8.0061, \mathrm{p}=0.0001$; $\mathrm{CV}=$ 4.415, MSD = 11.136, $\mathrm{p}=0.0024 ; \mathrm{CV}=4.199, \mathrm{MSD}=0.4733 ; \mathrm{p}=0.0002 ;{ }^{* * * *}$ Based on FT-NIR Spectroscopy - Thermo Fisher Scientific, Madison, WI USA. 

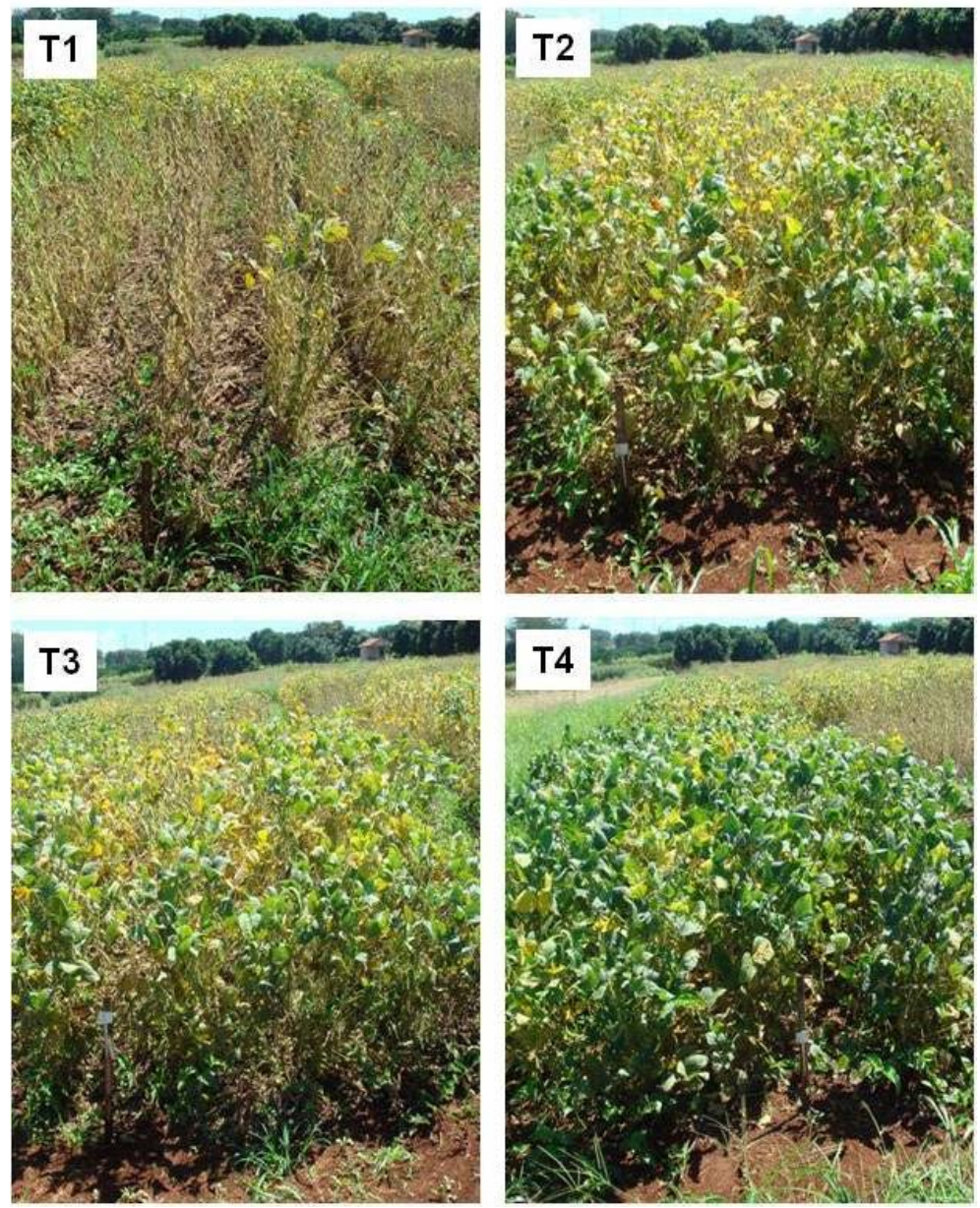

Figure 2. Effect of shale water either alone or in combination with pyraclostrobin on the severity of soybean rust 95 days after sowing. T1 = Check-without seed treatment and foliar application; T2 = Seeds treated with shale water (5\%) and three foliar applications of shale water (25\%); T3 = Seeds treated with shale water and three foliar applications with a mixture of shale water $(25 \%)+$ piraclostrobin $133 \mathrm{~g}^{-1}+$ epoxiconazol $50 \mathrm{~g}^{-1}$; $\mathrm{T} 4=$ Seeds treated with shale water and with three foliar applications of the fungicide piraclostrobin $133 \mathrm{~g}^{-1}+$ epoxiconazol $50 \mathrm{~g}^{-1}$ alone.

Table 5. Soybean seeds of field experiment with application of shale water alone or in combination with fungicide, infected with some major pathogens, seven days after incubation of blotter test.

\begin{tabular}{ccccc}
\hline \multirow{2}{*}{ Treatment $^{*}$} & & \multicolumn{2}{c}{ \% Seed transmitted pathogens } \\
\cline { 2 - 5 } & Aspergilus flavus $^{* * *}$ & ${\text { Cercospora } \text { kikuchi }^{* * *}}_{\text {Phomopsis sp. }^{* * * *}}$ & Fusarium semitectum $^{* * * * *}$ \\
\hline T1 & $4.8 \mathrm{a}$ & $5.3 \mathrm{~b}$ & $7.4 \mathrm{a}$ & $3.9 \mathrm{a}$ \\
T2 & $0.8 \mathrm{~b}$ & $12.4 \mathrm{a}$ & $0.4 \mathrm{~b}$ & $0.3 \mathrm{ab}$ \\
T3 & $0.1 \mathrm{~b}$ & $6.6 \mathrm{ab}$ & $0.4 \mathrm{~b}$ & $0.1 \mathrm{~b}$ \\
T4 & $0.1 \mathrm{~b}$ & $9.8 \mathrm{ab}$ & $0.2 \mathrm{~b}$ & $0.0 \mathrm{~b}$ \\
\hline
\end{tabular}

Figures are averages of four replications. ${ }^{*} \mathrm{~T} 1=$ Check-without seed treatment and foliar application; $\mathrm{T} 2=$ Seeds treated with shale water $(5 \%)$ and three foliar applications of shale water (25\%); $33=$ Seeds treated with shale water and three foliar applications with a mixture of shale water $(25 \%)+$ piraclostrobin $133 \mathrm{~g} \mathrm{~g}^{-1}+$ epoxiconazol $50 \mathrm{~g}^{-1}$; $\mathrm{T} 4=$ Seeds treated with shale water and with three foliar applications of the piraclostrobin $133 \mathrm{~g}^{-1}+$ epoxiconazol $50 \mathrm{~g}^{-1}$ fungicide alone. ${ }^{* *}$ Seed storage pathogen, $\mathrm{MSD}=2.83$ and $\mathrm{p}=0.0009 ;{ }^{* * * *} \mathrm{MSD}=6.11, \mathrm{p}=0.0202 ;{ }^{* * * *} \mathrm{MSD}=4.98 ; \mathrm{p}=0.0023$ ${ }^{* * *} \mathrm{MSD}=3.62, \mathrm{p}=0.0219$; $\mathrm{CV}$ was 4.2 for all the analyses; $F$ was significant for all the statistical analyses. Treatments with similar letters do not differ. Tukey $(\mathrm{p}=0.05)$.

\section{Discussion}

In field experiment conducted in 2014-2015, seed treatment and three foliar applications with shale water re- 
sulted in control efficiency of $24.8 \%$. Little higher control efficiency was obtained with foliar applications using pyraclostrobin + epoxiconazol alone or in combination with shale water than shale water applications alone. We did three foliar applications although our greenhouse results were positive even with seed treatment and one foliar application. This is because in the greenhouse experiments we inoculated the plants only once whereas under the natural field conditions the uredinospores are constantly brought by wind increasing thereby the inoculum pressure.

Considering the results of both greenhouse and field experiments, the outstanding point of the present investigation is that the seed treatment and only one foliar application of shale water would provide control of soybean rust.

The cost of three applications of a systemic fungicide for soybean is approximately US $\$ 60.00 /$ ha [1]. Since the cost of shale water is not yet released for commercial use in Brazil the cost benefit ratio compared with fungicidal applications cannot be evaluated. Future field experiments are needed using different soybean varieties to verify the minimum number of foliar applications as well as the longest interval between applications to achieve maximum control using shale water alone instead a synthetic fungicide.

Using shale water as a seed treatment and one foliar application on resistant or moderately resistant varieties may be an effective and cheaper alternative for farmers versus using multiple applications of systemic fungicides in Brazil. Consequently this would be a new perspective in reducing the severity of soybean rust epidemics and would help in reducing yield losses.

Different batches of shale water from different mining locations or the same location may have variation in the mineral composition. Besides, it is possible that there may be some factors affecting the properties of shale water including burial depth and the amount and the type of minerals present [18]. Irrespective of such variations, in the present study different batches of shale water from the same location were used during two years of greenhouse and field experimentation and the SAR activity of soybean to soybean rust was always consistent.

Besides, efficiency of the final composition of shale water (EAX) remained stable for over two years period when stored in dark at room temperature. This was determined in the in vitro tests using different batches of EAX originated from the same location considering their ability to inhibit development of Xanthomonas campestris pv. undulosa used as an indicator (unpublished data).

Miazawa and Gonçaçves [12] and Messias, 2011 [19] reported that the shale water contains very low amounts of toxic elements and contains no heavy metals and for this reason its use for foliar application may be safe.

While proteomic and other related studies are needed to conclusively demonstrate the basic mechanism of SAR activity of shale water, in the interim shale water can be used once it is officially recommended for commercial use in Brazil.

In Brazil seed treatment with shale water can be performed in the Seed Processing Units using 0.4 - 0.51 per $100 \mathrm{~kg}$ of concentrated shale water for large scale producers ( $>50 \mathrm{ha})$. However, further research is necessary to verify whether such shale water seed treatment would be effective to induce SAR.

The data of greenhouse and field experiments presented here indicate that the control efficiency of soybean rust was due to a systemic acquired resistance response. In both greenhouse experiments the treatment T4 without seed treatment but with one foliar application with shale water showed enhancement of SAR activity. SAR of common bean, cotton and soybean to $R$. solani and S. rolfsii induced by shale water seed treatment is recently reported by Mehta et al., 2015 [14]. However this is the first report of SAR of soybean induced by seed treatment and foliar application of shale water. Results obtained in the present investigation would serve as an incentive for future research with shale water. Patent regarding this investigation is deposited with Petrobras, Brazil, under the number EVP 14/022.

\section{Conclusions}

1) The reduction in soybean rust severity was due to a systemic acquired resistance response of shale water; 2) Results demonstrated that seed treatment and only one foliar application with shale water were sufficient to induce SAR against soybean rust and consequently reduce yield losses; 3) Results obtained in the present investigation would serve as an incentive for future research with shale water.

\section{Acknowledgements}

The present research was conducted under the financial support of Petrobras, Brazil. Thanks are due to Dr. Nel- 
son Fonseca Jr. for statistical analysis. Thanks are also due to Dr. A. A. Henning and A. I. Nagashima for their assistance in seed health testing. Technical assistance was provided by C. Zandoná, P. F. R. Alves, C. R. Bocatti, H. P. Rodrigues, T. S. Cunha, and M. P. Nunes. Field assistance was provided by J. Batista, L. Carlos and A. C. Campos.

\section{References}

[1] Yorinori, J.T., Paiva, W.M., Frederick, R.D. Costamilan, L.M., Bertagnolli, P.F., Hartman, G.E., Godoy, C.V. and Nunes Jr., J. (2005) Epidemics of Soybean Rust (Phakospora pachyrhizi) in Brazil and Paraguay from 2001 to 2003. Plant Disease, 89, 675-677.

[2] Hartman, G.L., Sinclair, J.B. and Rupe, J.C. (1999) Compendium of Soybean Diseases. 4th Edition, APS Press, St. Paul.

[3] Sá, H.S. and Azevedo, D.B. (2012) Pirataria de sementes: Influências e riscos para o agronegocio Brasileiro. Revista da ABPI, No. 120, Set/Oct, 2012.

[4] Durant, W.E. and Dong, X. (2004) Systemic Acquired Resistance. Annual Review of Phytopathology, 42, 185-209. http://dx.doi.org/10.1146/annurev.phyto.42.040803.140421

[5] Görlach, J., Volrath, S., Knauf-Beiter, G., et al. (1996) Benzoithiadizole, a Novel Class of Inducers of Systemic Acquired Resistance, Activates Gene Expression and Disease Resistance in Wheat. The Plant Cell, 8, 629-643. http://dx.doi.org/10.1105/tpc.8.4.629

[6] Vigo, S.C., Maringoni, A.C., Camara, R.C. and Lima, G.P.P. (2012) Evaluation of Pyraclostrobin and Acibenzolar-SMetyl on Common Bacterial Blight of Snap Bean. Semina: Ciências Agrárias, 33, 167-174. http://dx.doi.org/10.5433/1679-0359.2012v33n1p167

[7] Soares, R.M., Maringoni, A.C. and Lima, G.P.P. (2004) Ineficiência de Acibenzolar-S-Methyl na indução de resistência de feijoeiro comum à murcha-de-curtobacterium. Fitopatologia Brasileira, 29, 373-377. http://dx.doi.org/10.1590/S0100-41582004000400002

[8] Zhang, V., Wang, X., Cheng, C., Gao, Q., Liu, J. and Guo, X. (2008) Molecular Cloning and Characterization of GhNPR1, a Gene Implicated in Pathogen Responses from Cotton (Gossypium hirsutum L.). Bioscience Reports, 28, 714. http://dx.doi.org/10.1042/BSR20070028

[9] Metzger, W.C., Klein, D.A. and Redente, E.F. (1986) Bacterial Physiological Diversity in the Rhizosphere of Range Plants in Response to Retorted Shale Stress. Applied and Environmental Microbiology, 52,765-770.

[10] Schwab, A.P., Lindsay, Y.L. and Smith, P.J. (1983) Elemental Contents of Plants Growing on Soil-Covered Retorted Shale. Journal of Environmental Quality, 12, 301-304. http://dx.doi.org/10.2134/jeq1983.00472425001200030001x

[11] Stark, J.M. and Redente, E.F. (1990) Plant Uptake and Cycling of Trace Elements on Retorted Shale Disposal Piles. Journal of Environmental Quality, 19, 495-501. http://dx.doi.org/10.2134/jeq1990.00472425001900030023x

[12] Miazawa, M. and Gonçalves, P. (2009) Uso agricola de subproduto do processamento do xisto pirobetuminoso-agua de xisto. Technical Report, Iapar/Petrobras/Fapeagro, Fevereiro, 2009.

[13] Messias, R., Ferreira, L., H.G., Pereira, B.F., Silveira, C.A.P. and Pillon, C.N. (2010) Caracterização físico-química ds água de xisto visando seu uso como insumo para a agricultura. Anais I Congresso Brasileiro de Rochagem 21 a 24 de Setembro de 2009. Embrapa Cerrados, 2010.

[14] Mehta, Y.R., Marangoni, M.S., Bocatti, C.R., Heliosa, P., Rodrigues, T., Cunha, S. and Galbieri, R. (2015) Systemic Acquired Resistance of Cotton, Soybean and Common Bean to Rhizoctonia solani and Sclerotium rolfsii Induced by Shale Water Seed Treatment. American Journal of Plant Sciences, 6, 1493-1500. http://dx.doi.org/10.4236/ajps.2015.69148

[15] Fehr, W.R., Caviness, C.E. and Pennington, J.S. (1971) Stage of Development Descriptions for Soybeans, Glycine max (L). Merril. Crop Science, 11, 929-931. http://dx.doi.org/10.2135/cropsci1971.0011183X001100060051x

[16] Godoy, C.V., Koga, L.J. and Canteri, M.G. (2006) Diagramatic Scale for Assessment of Soybean Rust Severity. Fitopatologia Brasileira, 31, 63-68. http://dx.doi.org/10.1590/S0100-41582006000100011

[17] Heil, C. (2010) Rapid, Multi-Component Analysis of Soybeans by FT-NIR Spectroscopy. Madison: Thermo Fisher Scientific (Application Note: 51954). http://www.nicoletcz.cz/userfiles/file/vjecy/soybeans.pdf

[18] Oleas, A., Osuji, C.A., Chenevert, M.E. and Sharma, M.M. (2008) Entrance Pressure of Oil Based Mud into Shale: Effect of Shale Water Activity and Mud Properties. Society of Petrolium Engineers, Annul Technical Conference Exebition, Denver, 21-24 September.

[19] Messias, C. (2011) Respostas bioquimico-fisiológicas e agronômicas em alface e milho em função da aplicação de água de xisto. Doctorate Thesis in Science and Agroindustrial Technology, Faculdade de Agronomia Eliseu Maciel, Universidade Federal de Pelotas, RS, Brazil, 152. 